\title{
RESISTENSI INSULIN PADA REMAJA STUNTED OBESITY USIA 15-18 TAHUN DI KOTA SEMARANG
}

\author{
Ismi Safitri Nuraini, Muhammad Sulchan, Fillah Fithra Dieny ${ }^{*}$ \\ *) Program Studi Ilmu Gizi Fakultas Kedokteran Universitas Diponegoro \\ Jln. Prof. H. Soedarto, SH., Semarang, Telp (024) 8453708, Email : gizifk@undip.ac.id
}

\begin{abstract}
Background: Stunted obesity is a neglected nutritional problem, eventhough it is related to several degenerative and non-communicable diseases. Adolescents with stunted obesity has higher glucose and insulin level than adolescents with stunted non-obesity. They also tend to undergo insulin resistance and disfunction of pancreatic beta cell. Insulin resistance is included in clinical manifestation of metabolic syndrome in adolescents. The aim of this study is to analyze the different of insulin resistance between tunted obese and non-stuted obese adolescent.

Methods: This study was performed $n$ adolescents aged 15 to 18 years in Semarang with the spread of the territory is divided into two areas, urban and suburban. This was a cross-sectional study of 52 adolescent subjects taken consecutively from those schools. Insulin resistance level was measured with homeostasis model assessment insulin resistance (HOMA-IR). The difference of HOMA-IR was analyzed by Mann Whitney test.

Results: Insulin resistance in both category has the same percentage (96,1\%). Mean of HOMA-IR level in stunted obesity group $(5,37 \pm 4,86)$ wwas higher than non-stunted obese $(4,99 \pm 2,02)$, with $p=0,22$. There is subject in stunted obese group who has HOMA-IR level 19,66.

Conclusions: Both group has same trend of insulin resistance with $p=0,22$..

Keywords: stunted obese, non-stunted obese, fasting blood glucose, fasting blood insulin, insulin resistance
\end{abstract}

\begin{abstract}
ABSTRAK
Latar Belakang: Stunted obesity merupakan masalah gizi yang masih belum banyak mendapat perhatian walaupun terkait dengan berbagai penyakit degeneratif dan penyakit tidak menular lainnya. Remaja stunted obesity memiliki kadar glukosa, kadar insulin, resistensi insulin yang lebih tinggi, dan menurunnya fungsi sel- $\beta$ pankreas dari pada remaja stunted non-obese. Resistensi insulin merupakan salah satu kriteria klinis sindrom metabolik yang telah banyak muncul sejak usia remaja. Tujuan dari peenlitian ini adalah menganilisi perbedaan resistensi insulin antar kelompok stunted obese dan non-stunted obese.

Metode: Penelitian pada remaja usia 15 hingga 18 tahun di SMA Kota Semarang dengan persebaran wilayah dibagi menjadi dua wilayah yaitu urban dan suburban. Desain penelitian cross sectional dengan jumlah subjek 52 remaja menggunakan metode consecutive sampling. Nilai resistensi insulin didapatkan berdasarkan hasil perhitungan homeostasis model assessment insulin resistance (HOMA-IR). Perbedaan nilai HOMA-IR dianalisis menggunakan uji Mann Whitney.

Hasil: Ditemukan kejadian resistensi insulin pada kedua kelompok sama besar yaitu 96,1\%. Rerata nilai HOMA-IR pada

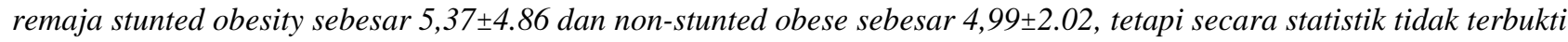
bemakna $(p=0,22)$.
\end{abstract}

Kesimpulan: Kedua kelompok mempunyai kecenderungan yang sama untuk mengalami resistensi insulin dengan $p=0,22$..

Kata Kunci: stunted obese, non-stunted obese, GDP, insulin puasa, resistensi insulin

\section{PENDAHULUAN}

Indonesia saat ini berada dalam fenomena double burden masalah gizi remaja dengan jumlah populasi sepertiga penduduk. Menurut data Riskesdas 2013, pada remaja berusia 16-18 tahun terdapat $31,4 \%$ remaja pendek dengan $7,5 \%$ tergolong sangat pendek dan $23,9 \%$ pendek ${ }^{1}$. Sedangkan prevalensi remaja gemuk mencapai 7,3\% yang terdiri dari 5,7\% gemuk dan 1,6\% obesitas. Prevalensi remaja gemuk mengalami peningkatan lebih dari lima kali lipat selama tiga tahun dari $1,4 \%$ pada tahun 2010 menjadi $7,3 \%$ pada tahun $2013^{1}$. Prevalensi remaja pendek Jawa Tengah sebesar 26,3\% (4,9\% sangat pendek dan $21,4 \%$ pende k) dan prevalensi remaja gemuk sebesar
$7,1 \%(5,4 \%$ gemuk dan $1,7 \%$ obesitas), dan Kota Semarang memiliki prevalensi remaja obesitas sebanyak 3,3\%, dua kali lipat dari pada prevalensi nasional ${ }^{2}$. Oleh karena itu, permasalah gizi stunted dan obesitas pada remaja merupakan hal utama yang harus diperhatikan.

Stunted obesity merupakan masalah gizi yang masih belum banyak mendapat perhatian. Stunted obesity adalah keadaan gizi seseorang yang memiliki tubuh pendek dan obesitas. Beberapa penelitian tentang prevalensi stunted obesity telah dilakukan di berbagai negara. Tahun 2000, jumlah anak yang menderita stunted obesity di negara-negara Amerika Latin sebesar $13.7 \%^{3}$. Brazil pada tahun 2003 
terdapat 22,6\% penduduk stunted dan 30\% diantara tergolong overweight dan obesitas ${ }^{4}$.

Stunted obesity erat kaitannya dengan berbagai penyakit terutama penyakit degeneratif dan penyakit tidak menular lainnya. Hal ini berkaitan dengan hipotesis yang dikemukan oleh Barker yang menyatakan bahwa, "Penyakit kronis pada masa dewasa telah terprogram sejak dalam masa kandungan"5. Hal ini dapat terjadi karena anak stunted memiliki gangguan sistem endokrin yang menyebabkan kecepatan oksidasi lemak yang lebih rendah sehingga lemak yang tidak teroksidasi harus disimpan sebagai cadangan dan pada akhirnya akan menumpuk ${ }^{6}$. Penelitian yang telah dilakukan sebelumnya dibeberapa negara seperti Afrika Selatan dan Brazil menunjukkan hasil bahwa anak stunted mempunyai risiko untuk mengalami overweight. Sebanyak 14,8\% siswa sekolah menengah di Afrika Selatan mengalami stunted dan terdapat kecenderungan mengalami overweight ${ }^{7}$. Selain itu, $45,1 \%$ remaja stunted di Rusia mengalami overweight dengan rasio risiko sebesar 1,7-7,8 $\mathrm{kali}^{8}$.

Penelitian dengan melibatkan 66 remaja stunted di Sao Paulo, Brazil didapatkan hasil remaja stunted obesity memiliki kadar glukosa, kadar insulin, dan resistensi insulin yang lebih tinggi dan menurunnya fungsi sel- $\beta$ pankreas dari pada remaja stunted non-obese ${ }^{9}$. Resistensi insulin merupakan salah satu faktor risiko sindrom metabolik yang telah banyak muncul sejak usia remaja dan menjadi penyebab yang pertama muncul yang berhubungan dengan kriteria klinis sindrom metabolik seperti diabetes melitus tipe 2 (DM Tipe 2), dislipidemia, dan hipertensi ${ }^{10,11,12,13,14,15}$. Hal ini dikarenakan insulin menyebabkan ginjal meningkatkan reabsorbsi natrium dan meningkatkan volume plasma yang dapat menyebabkan hipertensi. Selain itu insulin juga dapat meningkatkan produksi Very Low Density Lipoprotein (VLDL) dan Trigliserida (TG) ${ }^{16,17}$.

Berdasarkan latar belakang tersebut maka perlu diteliti tentang resistensi insulin pada remaja berusia 15 hingga 18 tahun di SMA Kota Semarang. Adanya pendeteksian dini terkait resistensi insulin diharapkan mampu meningakatkan kewaspadaan terhadap faktor risiko sindrom metabolik.

\section{METODE}

Penelitian ini merupakan penelitian observasional dengan rancangan penelitian cross sectional study dimana peneliti melakukan pengukuran sebanyak satu kali pengukuran. Subjek penelitian merupakan remaja siswa-siswi SMA di Kota Semarang yang diambil secara cluster random sampling pada daerah urban dan suburban. SMA yang berada pada daerah urban yaitu SMAN 1 Semarang dan SMA PGRI 1 Semarang. Sedangkan
SMA yang berada pada daerah suburban yaitu SMAN 12 Semarang dan MA NU Nurul Huda Tugu. Kriteria inklusi dari penelitian ini adalah remaja usia 15-18 tahun yang mengalami obesitas dengan indikator lingkar pinggang laki-laki $>90 \mathrm{~cm}$ dan perempuan $>80 \mathrm{~cm}$, termasuk dalam golongan stunted dengan $z$ score $\mathrm{TB} / \mathrm{U}<-2 \mathrm{SD}$ atau termasuk dalam golongan non-stunted dengan z-score $\mathrm{TB} / \mathrm{U} \geq-2 \mathrm{SD}$, tidak mengonsumsi suplemen dan/atau obat-obatan anti diabetes, dan bersedia menjadi subjek penelitian dengan mengisi inform consent. Pemilihan subjek menggunakan metode cluster random sampling dan consecutive sampling.

Variabel terikat (dependent) dalam penelitian ini adalah resistensi insulin, sedangkan variabel bebas (independent) dalam penelitian ini adalah stunted obesity. Stunted obesity merupakan keadaan status gizi seseorang yang tergolong obesitas yang didahului oleh keadaan stunted. Stunted obesity didapatkan berdasarkan status gizi dengan perhitungan z-score $\mathrm{TB} / \mathrm{U}<-2 \mathrm{SD}$ dan lingkar pinggang laki-laki $>90 \mathrm{~cm}$ dan perempuan $>80 \mathrm{~cm}$. Non-stunted obesity merupakan keadaan status gizi seseorang yang tergolong obesitas tetapi tidak didahului oleh keadaan stunted. Non-stunted obesity didapatkan berdasarkan status gizi dengan perhitungan $z$-score $\mathrm{TB} / \mathrm{U}>-2 \mathrm{SD}$ dan lingkar pinggang laki-laki $>90 \mathrm{~cm}$ dan perempuan $>80 \mathrm{~cm}$ yang diukur menggunakan skala nominal. Resistensi insulin adalah gangguan respon biologis terhadap insulin dengan akibat kebutuhan insulin tubuh meningkat sehingga terjadi hiperinsulinemia untuk mempertahankan kadar glukosa plasma agar dalam keadaan normal. Kadar resistensi insulin didapatkan berdasarkan hasil perhitungan homeostasis model assessment insulin resistance (HOMA-IR) dengan rumus $\frac{\text { Insulin puasa }\left(\frac{m U}{L}\right) x \text { Glukosa puasa }\left(\frac{m m o l}{L}\right)}{22,5} 18$. Ambang batas nilai normal HOMA-IR untuk remaja adalah $<1.65^{19}$. Pengambilan sampel darah dilakukan oleh petugas ahli yang berasal dari Laboratorium RSUP Dr Kariadi Semarang. Darah diambil melalui vena mediana cubiti pada jam 07.00 - 09.00 WIB sebanyak $3 \mathrm{cc}$ setelah subjek melakukan puasa selama delapan hingga sepuluh jam. Pemeriksaan kadar insulin puasa dilakukan di Laboratorium GAKI Fakultas Kedokteran Universitas Diponegoro Semarang, dengan metode enzyme-linked immunosorbent assay (ELISA) dianalisis dengan Dynex MRX II microplate-reader yang dibaca pada panjang gelombang $450 \mathrm{~nm}^{20}$. Ambang batas kadar normal insulin puasa adalah $2-25 \mu \mathrm{U} / \mathrm{L}^{21}$. Sedangkan untuk pemeriksaan Gula Darah Puasa (GDP) dilakukan di Laboratorium Sarana Medika Semarang, dengan metode reaksi enzimatik polimetrik menggunakan automatic kit yang dibaca pada 
panjang gelombang $546 \mathrm{~nm}$. GDP dikatakan normal apabila berada pada kadar $<100 \mathrm{mg} / \mathrm{dL}$, sedang antara $100-125 \mathrm{mg} / \mathrm{dL}$, dan tinggi apabila kadar $>125$ $\mathrm{mg} / \mathrm{dL}^{22}$.

Skrining dilakukan terhadap 2.299 remaja. Tinggi badan diukur menggunakan microtoise dengan ketelitian $0.1 \mathrm{~cm}$. Lingkar pinggang diukur menggunakan pita ukur metline dengan ketelitian 0.1 $\mathrm{cm}$.

Uji perbedaan resistensi insulin antara siswa stunted obese dan non-stunted obese digunakan uji statistik Mann Whitney Test.

\section{HASIL PENELITIAN \\ Penelitian Pendahuluan}

Hasil skrining dari 2.299 remaja menunjukkan 269 remaja $(11,7 \%)$ mengalami stunted, 359 remaja $(15,6 \%)$ mengalami obesitas, 314 remaja $(13,7 \%)$ mengalami non-stunted obese, dan 45 remaja (2\%) mengalami stunted obese. Data skrining awal menunjukkan bahwa prosentase remaja obesitas di daerah urban lebih banyak dari pada daerah suburban. Pada daerah urban ditemukan 2,2\% (18 remaja) yang tergolong stunted obese dan 12,2\% (73 remaja) tergolong non-stunted obese. Sedangkan pada daerah suburban hanya terdapat 1,8\% (27 remaja) tergolong stunted obese dan 14,5\% (214 remaja) tergolong non-stunted obese. Gambaran status gizi remaja ditampilkan pada tabel 1.

Tabel 1. Gambaran Status Gizi pada Populasi Remaja

\begin{tabular}{lrrr}
\hline \multicolumn{1}{c}{ Status Gizi } & Urban $(\mathrm{n}=823)$ & Suburban $(\mathrm{n}=1.476)$ & Total $(\mathrm{n}=2.299)$ \\
\hline Underweight & $37(4,5 \%)$ & $111(7,5 \%)$ & $148(6,4 \%)$ \\
Normal & $582(70,7 \%)$ & $941(63,8 \%)$ & $1.523(66,2 \%)$ \\
Stunted & $86(10,4 \%)$ & $183(12,4 \%)$ & $269(11,7 \%)$ \\
Stunted Obese & $18(2,2 \%)$ & $27(1,8 \%)$ & $45(2 \%)$ \\
Non-stunted Obese & $100(12,2 \%)$ & $214(14,5 \%)$ & $314(13,7 \%)$ \\
Total & $823(100 \%)$ & $1.476(100 \%)$ & $2.299(100 \%)$ \\
\hline
\end{tabular}

Ket : Undereight (z-score IMT/U <-2SD; z-score TB/U >-2 SD)

Normal (z-score IMT/U >-2SD; $z$-score TB/U >-2 SD)

Stunted (z-score IMT/U >-2SD; $z$-score TB/U <-2 SD)

Stunted Obese (LP laki-laki $>90 \mathrm{~cm}$; LP perempuan $>80 \mathrm{~cm}$; z-score TB/U <-2 SD)

Non-stunted Obese (LP laki-laki $>90 \mathrm{~cm}$; LP perempuan $>80 \mathrm{~cm}$; z-score TB/U >-2 SD)

\section{Karakteristik Subjek}

Karakteristik subjek terdiri dari usia, jenis kelamin, dan status gizi yang digunakan untuk mendeskripsikan subjek penelitian secara jelas dan sistematis. Sebanyak 21 subjek $(40,38 \%)$ berusia 15 tahun, 12 subjek $(23,07 \%)$ berusia 16 tahun, 16 subjek $(30,76 \%)$ berusia 17 tahun, dan 3 subjek $(5,76 \%)$ berusia 18 tahun. Terdapat $11,5 \%$ subjek stunted obesity berjenis kelamin laki-laki dan $88,46 \%$ berjenis kelamin perempuan. Sedangkan subjek penelitian pada kelompok non-stunted obesity sebanyak $65,38 \%$ berjenis kelamin laki-laki dan $23,07 \%$ berjenis kelamin perempuan. Setelah dilakukan uji Chi-Square pada jenis kelamin subjek ditemukan hasil bahwa terdapat hubungan signifikan antara jenis kelamin dengan kejadian stunted obesity dengan $\mathrm{p}=0.0001$.

Tabel 3 menunjukkan bahwa dari 52 sampel, 26 sampel merupakan kelompok stunted obesity dan 26 sampel merupakan kelompok non-stunted obesity.

Tabel 2. Gambaran Jenis Kelamin berdasarkan Status Gizi Subjek

\begin{tabular}{|c|c|c|c|}
\hline \multirow{3}{*}{ Jenis Kelamin } & \multicolumn{2}{|c|}{ Status Gizi } & \multirow{3}{*}{$\mathrm{p}$} \\
\hline & Stunted Obese $\mathrm{n}=26$ & Non-stunted Obese $\mathrm{n}=26$ & \\
\hline & $\mathrm{n} \%$ & $\mathrm{n} \%$ & \\
\hline Laki-laki & $3(11,5 \%)$ & $17(65,4 \%)$ & \multirow{3}{*}{$0,001^{\mathrm{a}}$} \\
\hline Perempuan & $23(88,5 \%)$ & $9(34,6 \%)$ & \\
\hline Total & $26(100 \%)$ & $26(100 \%)$ & \\
\hline
\end{tabular}

Tabel 3. Nilai Minimum, Maksimum, dan Rerata Lingkar Pinggang dan TB/U

\begin{tabular}{lrrrr}
\hline \multirow{2}{*}{ Karakteristik } & \multicolumn{2}{c}{ Stunted Obese $\mathrm{n}=26$} & \multicolumn{2}{c}{ Non-stunted Obese $\mathrm{n}=26$} \\
\cline { 2 - 5 } & Rerata \pm SD & Median (Min-Maks) & Rerata \pm SD & Median (Min-Maks) \\
\hline Lingkar Pinggang (cm) & $91,23 \pm 7,5$ & $91,5(80,6-101,65)$ & $95,91 \pm 9,04$ & $96,05(80,35-110,4)$ \\
TB/U (SD) & $-2,32 \pm 0,38$ & $-2,3(-3,14-(-1,79))$ & $-0,83 \pm 0,55$ & $-0,83(-1,71-0,4)$ \\
\hline
\end{tabular}


Tabel 4. Gambaran Nilai GDP, Insulin Puasa, dan HOMA-IR berdasarkan Status Gizi Subjek

\begin{tabular}{lrrrr}
\hline \multirow{2}{*}{ Variabel } & Nilai & \multicolumn{2}{c}{ Status Gizi } & \\
\cline { 3 - 4 } & & $\begin{array}{c}\text { Stunted Obese } \mathrm{n}=26 \\
\mathrm{n} \%\end{array}$ & $\begin{array}{c}\text { Non-stunted Obese } \mathrm{n}=26 \\
\mathrm{n} \%\end{array}$ & Total \\
\hline GDP & Normal & $25(96,1 \%)$ & $26(100 \%)$ & $51(98 \%)$ \\
& Sedang & $1(3,9 \%)$ & - & $1(2 \%)$ \\
Insulin Puasa & Normal & $17(65,4 \%)$ & $15(57,7 \%)$ & $32(61,5 \%)$ \\
& Tinggi & $9(34,6 \%)$ & $11(42,3 \%)$ & $20(38,5 \%)$ \\
HOMA-IR & Normal & $1(3,9 \%)$ & $1(3,9 \%)$ & $2(3,9 \%)$ \\
& Tinggi & $25(96,1 \%)$ & $25(96,1 \%)$ & $50(96,1 \%)$ \\
\hline
\end{tabular}

Tabel 4 menunjukkan distribusi frekuensi nilai GDP, Insulin Puasa, dan HOMA-IR antar kelompok yang telah dibagi dalam beberapa kategori. Pada masing-masing kelompok hanya terdapat $3,88 \%$ (satu subjek) yang memiliki nilai HOMA-IR dalam ambang batas normal.

\section{Perbedaan Resistensi Insulin (HOMA-IR) antara Kelompok Stunted Obesity dan Non-Stunted Obesity}

Tabel 5 menunjukkan uji perbedaan rerata nilai HOMA-IR stunted obese sebesar 5,37 \pm 4.86 dan non-stunted obese sebesar 4,99 \pm 2.02 dengan $\mathrm{p}=0,22$ yang berarti terdapat perbedaan rerata nilai HOMA-
IR antara kelompok stunted obese dan non-stunted obese, namun secara statistik tidak bermakna.

Uji korelasi dilakukan untuk melihat hubungan data GDP, Insulin Puasa, dan HOMA-IR dengan data antropometri. Tabel 6 menunjukkan terdapat hubungan yang lebih signifikan antara data GDP, Insulin Puasa, dan HOMA-IR dengan lingkar pinggang dibandingkan dengan $\mathrm{TB} / \mathrm{U}$. Hal ini bisa disebabkan karena tidak dapat dilakukan matching lingkar pinggang subjek sehingga terdapat variasi nilai lingkar pinggar yang terlalu besar sehingga mempengaruhi data GDP, Insulin Puasa, dan HOMAIR.

Tabel 5. Nilai Minimum, Maksimum, dan Rerata Nilai GDP, Insulin Puasa, dan HOMA-IR

\begin{tabular}{|c|c|c|c|c|c|}
\hline \multirow[b]{2}{*}{ Karakteristik } & \multicolumn{2}{|c|}{ Stunted Obese $\mathrm{n}=26$} & \multicolumn{2}{|c|}{ Non-Stunted Obese $\mathrm{n}=26$} & \\
\hline & Mean \pm SD & Median (Min-Maks) & Mean $\pm \mathrm{SD}$ & Median (Min-Maks) & \\
\hline $\mathrm{G}$ & 84 , & & $86,65=$ & 87,5 & $0,33^{\mathrm{b}}$ \\
\hline $\begin{array}{l}\text { Insulin Puasa } \\
(\mu \mathrm{U} / \mathrm{L})\end{array}$ & 25, & 3) & ,21 & ,68) & $0,3^{\mathrm{c}}$ \\
\hline HOMA-IR & $5,37 \pm 4,86$ & $3,89(1,35-19,66)$ & $4,99 \pm 2,02$ & $5(0,87-8,72)$ & $0,22^{\mathrm{c}}$ \\
\hline
\end{tabular}

${ }^{\mathrm{b}}$ Independent sample t-test

'Mann Whitney test

Tabel 6. Hubungan Lingkar Pinggang dan TB/U dengan Nilai GDP, Insulin Puasa, dan HOMA-IR

\begin{tabular}{lrrrr}
\hline \multirow{2}{*}{ Karakteristik } & \multicolumn{2}{c}{ Lingkar Pinggang } & \multicolumn{2}{c}{ TB/U } \\
\cline { 2 - 5 } & \multicolumn{1}{c}{$\mathrm{r}$} & $\mathrm{p}$ & $\mathrm{r}$ & $\mathrm{p}$ \\
\hline GDP & 0,29 & 0,04 & 0,23 & $0,1^{\mathrm{d}}$ \\
Insulin Puasa & 0,39 & 0,004 & 0,15 & $0,28^{\mathrm{e}}$ \\
HOMA-IR & 0,47 & 0,000 & 0,15 & $0,2^{\mathrm{e}}$ \\
\hline
\end{tabular}

${ }^{\mathrm{d}}$ Pearson test

eSpearman test

\section{PEMBAHASAN}

Penelitian ini meneliti tentang efek stunting yang telah mengalami catch up growth pada kejadian resistensi insulin pada remaja. Kelompok kasus terdiri dari subjek stunted yang telah mengalami catch up growth dan pada kelompok kontrol terdiri dari subjek non-stunted obese. Individu stunted cenderung memiliki gangguan pada metabolisme glukosa terutama dikarenakan oleh resistensi insulin dan berisiko mengalami sindrom metabolik seperti DM Tipe 2, penyakit kardiovaskular, dan dislipidemia.
Dari hasil skrining diperoleh prosentase remaja yang mengalami obesitas lebih banyak terjadi di daerah urban. Hal ini dikarenakan masyarakat pada daerah urban mengalami perubahan gaya hidup seperti lebih sering mengonsumsi makanan padat energi yang jauh lebih mudah ditemui pada daerah urban dan lebih jarang melakukan aktivitas fisik ${ }^{23,24}$. Pendapatan perkapita penduduk pada daerah urban juga cenderung lebih tinggi daripada daerah suburban sehingga semakin mempermudah akses terhadap makanan padat energi yang mudah dijumpai ${ }^{25}$.

Jenis kelamin ditemukan mempunyai hubungan signifikan dengan kejadian stunted obesity 
( $\mathrm{p}=0.001$ ) seperti pada penelitian sebelumnya yang dilakukan di Barcelona dan Brazil ${ }^{26,18}$. Hal ini diakibatkan karena perempuan stunted mempunyai total energy expenditure (TEE) yang lebih rendah dari pada laki-laki sejak usia anak-anak sehingga berisiko lebih tinggi menderita obesitas ${ }^{27}$. Pada perempuan dikarenakan memiliki metabolisme basal yang lebih rendah, fat free mass yang lebih rendah sehingga energy yang dikeluarkan saat istirahat juga lebih rendah, dan aktifitas fisik yang lebih rendah sehingga energy yang dikeluarkan juga lebih rendah. Selain itu, perempuan juga memiliki massa lemak lebih tinggi dari pada laki-laki ${ }^{28,29}$.

Individu yang mengalami kekurangan energi kronis akan beradaptasi untuk dapat bertahan hidup dengan cara mengurangi pengeluaran energi seminimal mungkin. Adaptasi tersebut menyebabkan perubahan terhadap gen yang disebut sebagai thrifty $\mathrm{gen}^{30}$. Gen ini lama kelamaan akan memicu keadaan keseimbangan energi positif sehingga dalam jangka waktu lama akan menimbulkan kondisi overweight atau obesitas. Anak stunted cenderung memiliki kadar Insulin Growth Factor-1 (IGF-1) yang rendah dicurigai menjadi penyebab utama terhambatnya pertumbuhan anak ${ }^{31}$. Level IGF-1 yang rendah dapat merusak lipolisis, sebagai konsekuensinya, peningkatan lemak tubuh dapat terjadi karena berkurangnya kemampuan untuk mengoksidasi lemak dari makanan. Penurunan oksidasi lemak ini sebagai respon adaptif tubuh selama masa kekurangan energi kronis. Saat tubuh sudah mendapat asupan zat gizi yang memadai atau cenderung berlebih maka dapat terjadi kelebihan simpanan lemak $^{32}$. Asupan energi yang rendah selama pertumbuhan diketahui menurunkan level IGF-1 dan meningkatkan rasio kortisol terhadap insulin ${ }^{33}$. Metabolisme kortisol juga memiliki peran utama dalam distribusi lemak yang terpogram dari dalam kandungan. Jaringan lemak viseral memiliki jumlah reseptor glukokortikoid lebih tinggi dibandingkan dengan jaringan lemak lainnya. Oleh karena itu, paparan glukokortikoid seperti kortisol dapat menyebabkan penyerapan lemak yang lebih cepat pada jaringan lemak viseral, karena kortisol dapat meningkatkan aktivitas lipoprotein lipase (LPL) ${ }^{34}$. Simpanan lemak viseral yang paling sering digunakan sebagai tempat simpanan lemak, karena tubuh akan lebih mudah memecah lemak pada saat dibutuhkan. Selain itu pada remaja stunted juga terdapat penurunan metabolisme basal tubuh yang menyebabkan lemak menjadi atherogenik dan mengumpul pada jaringan lemak viseral ${ }^{31,6}$.

Berdasarkan hasil penelitian menunjukkan terdapat perbedaan rerata nilai HOMA-IR antara remaja stunted obese dan non-stunted obese walaupun tidak bermakna secara statistik. Kelompok stunted obese mempunyai rerata nilai HOMA-IR sebesar 5.37 \pm 4.86 dan non-stunted obese sebesar $4,99 \pm 2.02$ dengan $\mathrm{p}=0,22$. Masing-masing kelompok hanya terdapat $3,8 \%$ (satu subjek) yang masih memiliki nilai HOMA-IR dalam batas normal. Ditemukan pula subjek yang memiliki nilai HOMAIR sebesar 19,66 pada kelompok stunted obese sehingga remaja stunted obese lebih mudah mengalami resistensi insulin.

Dari 52 subjek penelitian hanya terdapat dua subjek yang masih memiliki nilai HOMA-IR normal, 32 subjek memiliki kadar Insulin Puasa normal dan 52 subjek memiliki kadar GDP normal. Hanya terdapat satu subjek pada kelompok stunted obese yang memiliki kadar GDP yang tergolong sedang. Hal ini sejalan dengan penelitian yang telah dilakukan sebelumnya pada tahun 2013 di Brazil dan 2014 di Semarang bahwa saat usia remaja belum terjadi hiperglikemi yang berarti tubuh masih bisa mengkompensasi metabolisme karbohidrat sehingga masih bisa mempertahankan kadar GDP normal ${ }^{35,36}$. Namun, yang menjadi perhatian adalah hanya terdapat dua subjek yang memiliki nilai HOMA-IR normal yang berarti 50 subjek lainnya telah mengalami resistensi insulin. Resistensi insulin merupakan faktor risiko sindrom metabolik yang pertama muncul sehingga tingginya kejadian resistensi insulin pada penelitian ini dapat meningkatkan risiko sindrom metabolik ataupun penyakit tidak menular lainnya yang dapat disebabkan oleh resistensi insulin ${ }^{11,12}$.

Resistensi insulin yang terjadi dalam kondisi obesitas viseral dianggap sebagai faktor utama dalam kejadian sindrom metabolik. Suatu studi menyebutkan bahwa asupan diet tinggi lemak menginduksi peningkatan adiposit viseral yang membentuk awal terjadinya resistensi insulin pada hati ${ }^{37}$. Pada awalnya peningkatan lemak dalam diet ditujukan untuk menyimpan cadangan lemak di lemak viseral dan subkutan, namun hati menjadi sensitif terhadap peningkatan jumlah lemak pada jaringan lemak viseral. Adanya asupan lemak yang berlebihan ini diikuti dengan perubahan ekspresi enzim (seperti Lipase lipoprotein, hormon sensitif Lipase, Peroxisome Proliferator-actived receptor- $\gamma$ ), membuat peningkatan produksi asam lemak bebas dari vena portal ke hati dan jaringan lain. Jumlah asam lemak bebas yang berlebihan kemudian merangsang pankreas untuk mensekresikan insulin dalam jumlah banyak, namun tidak cukup mengendalikan hiperglikemi yang ditandai dengan peningkatan kadar glukosa darah puasa. Insulin dalam jumlah banyak juga mempercepat sintesis trigliserida di hati dan jaringan adiposa, akibatnya terjadi peningkatan transport trigliserida pada partikel HDL yang dibuat oleh lipase hepatik. Keadaan ini 
merangasang hidrolisis trigliserida yang membuat kondisi hipertrigliseridemia dan penurunan kadar HDL. Resistensi insulin juga menurunkan kemampuan vasodilatasi pembuluh darah dan meningkatkan resorbsi garam, yang membuat Angiotensin II menyebabkan vasokonstriksi pembuluh darah dan peningkatan tekanan darah ${ }^{38,39}$. Mekanisme resistensi insulin ini yang dipercaya menjadi pemicu awal munculnya tanda dari sindrom metabolik.

Pada penelitian ini menunjukkan rata-rata resistensi insulin pada kelompok stunted obese lebih tinggi daripada kelompok non-stunted obese dan pada kelompok stunted obese ditemukan subjek yang memiliki nilai HOMA-IR sebsar 19,66 yang sejalan dengan beberapa penelitian yang telah dilakukan sebelumnya ditemukan beberapa penyebab terjadinya resistensi insulin pada individu stunted. "Fetal Salvage" teori menjelaskan pada janin stunted mereka mulai menunjukkan tanda-tanda resistensi insulin perifer yang menyebabkan penurunan fungsi dan jumlah transporter glukosa otot rangka ${ }^{40,41}$. Penurunan ini berkaitan dengan penurunan IGF-1 pada individu stunted yang mengakibatkan terganggunya pertumbuhan sel otot rangka. Penurunan sensitivitas insulin ini merangsang sel-sel untuk menghasilkan insulin dalam jumlah banyak untuk menyeimbangkan kadar glukosa dalam tubuh dan lama-kelamaan akan terjadi kelelahan pada sel $\beta$ pankreas. Padahal bayi stunted memiliki jumlah stem cell yang lebih sedikit sehingga kemampuan untuk meregenerasi atau memperbaiki kerusakan diri sendiri lebih terbatas ${ }^{42}$. Hal ini dapat memperburuk keadaan kelelahan pada sel $\beta$ pankreas yang dapat terjadi lebih dini. Pada anak-anak stunted berusia enam tahun di China ditemukan sekresi insulin lebih banyak untuk mengimbangi proses resistensi insulin $^{43}$. Kadar GH yang tinggi dan IGF-1 yang rendah juga turut berkontribusi terjadinya resistensi insulin pada individu stunted. Kadar GH yang tinggi dapat meningkatkan lipolisis dan asam lemak bebas $(\text { FFA })^{44}$. Pada anak stunted sejak dini juga ditemukan memiliki faktor inflamasi yang tinggi seperti TNF- $\alpha$, IL-6, dan CRP ${ }^{45,46}$. TNF- $\alpha$ adalah adipokin pertama yang disekresi oleh adiposit. Ketika adiposit mensekresi TNF- $\alpha$, persinyalan insulin telah rusak, terutama karena perubahan dalam transkripsi molekul sinyal insulin, khususnya reseptor insulin, IRS-1 dan glucose transporter 4 (GLUT-4). TNF- $\alpha$ dapat menyebabkan resistensi insulin di adiposit, hepatosit, dan otot rangka ${ }^{47}$. Selain TNF- $\alpha$ sekresi yang meningkat saat obesitas oleh adiposit dan makrofag adalah IL-6. Kadar IL-6 yang meningkat, menyebabkan perlambatan sinyal insulin pada sel adiposa dan hepatosit yang berimbas pada resitensi insulin ${ }^{47}$.
Ditemukan hubungan yang lebih kuat antara resistensi insulin dan lingkar pinggang daripada resistensi insulin dengan TB/U. hal ini dapat disebabkan karena keadaan obesitas meningkatkan pelepasan asam lemak bebas dan abnormalitas sekresi adipokin. Lemak viseral dan subkutan mempunyai mekanisme yang sedikit berbeda terkait hal ini. Lemak viseral lebih tidak sensitive terhadap efek antilipolitik insulin sehingga menyebabkan lebih lipolitik daripada lemak subkutan. Asam lemak bebas yang dilepaskan dari simpanan lemak viseral langsung menuju hati. Peningkatan jumlah asam lemak bebas dari lemak viseral menuju dapat meningkatkan glukoneogenesis dan resistensi insulin hepatik dan mempercepat sintesis VLDL dan meningkatkan kadar Trigliserida. Simpanan Trigliserida pada subjek obesitas dialihkan dari sel atau jaringan adiposit ke sel atau jaringan nonadiposit seperti ke hepatosit dan otot rangka. Akumulasi lemak yang berada di sel atau jaringan non-adiposit akan meningkatkan resistensi insulin dengan mengganggu jalur persinyalan insulin ${ }^{48,49}$. Selain itu pada subjek obesitas akan lebih banyak memproduksi faktor inflamasi yang dapat memperburuk kejadian resistensi insulin ${ }^{49}$. Peningkatan lemak viseral berhubungan positif dengan terjadinya resistensi insulin. Peningkatan massa lemak viseral sebanyak $0,5 \mathrm{~kg}$ hingga $2 \mathrm{~kg}$ dapat menurunkan $65 \%$ uptake glukosa di jaringan abdominal maupun jaringan otot ${ }^{50}$.

Keterbatasan dari penelitian ini yang dapat dicurigai menyebabkan tidak ada perbedaan bermakna secara statistik adalah tidak adanya kontrol terhadap aktifitas fisik subjek dan hereditas penyakit diabetes orang tua. Pada kedua kelompok mempunyai frekuensi olahraga yang sama di sekolah yaitu satu kali setiap minggu dengan durasi 90 menit. Tetapi peneliti susah untuk mendapatkan data olahraga di luar waktu sekolah sehingga dapat menambah potensi bias dalam penelitian ini. Aktivitas fisik memiliki efek pada sensitivitas insulin pada subjek sehat dan juga pada subjek dengan kelainan metabolik. Pengaruh kebiasaan olahraga pada sensitivitas insulin dalam metabolisme lipid melalui peningkatan transportasi glukosa dan metabolisme glukosa termasuk regulasi output glukosa hepatik ${ }^{51}$. Aktivitas fisik juga dapat meningkatkan transpor glukosa ke dalam sel-sel otot, dengan mengatur ekspresi GLUT 4. Selain itu, aktivitas fisik secara teratur mengurangi massa lemak dan menggantikannya dengan massa otot, sehingga terdapat peningkatan massa otot untuk penyerapan glukosa ${ }^{52}$. Aktifitas fisik selama 12 minggu dengan intensitas tinggi seperti berlari dengan frekuensi tiga sampai empat kali seminggu dengan durasi 30 menit dapat meningkatkan sensitivitas insulin hingga $28 \%{ }^{53}$. Selain kebiasaan 
olahraga, peneliti juga mengalami kesulitan dalam penggalian data hereditas subjek. Individu dengan riwayat DM Tipe 2 pada keluarga mempunyai risiko yang lebih besar terhadap ganguan toleransi glukosa, resistensi insulin, disfungsi dari sel $\beta$ pankreas, dan rendahnya kadar IGFBP- $1^{54,55}$.

\section{SIMPULAN}

Kategori resistensi insulin pada kedua kelompok sama besar yaitu $96,1 \%$. Rerata nilai HOMA-IR pada remaja stunted obesity lebih tinggi $(5,37 \pm 4,86)$ dibandingkan dengan remaja non-stunted obese $(4,99 \pm 2,02)$, tetapi secara statistik tidak terbukti bemakna. Terdapat subjek yang memiliki nilai HOMA-IR mencapai 19,66 pada kelompok stunted obese.

\section{SARAN}

Dilakukannya edukasi kepada remaja tentang pentingnya menjaga berat badan ideal dan mencapai tinggi badan optimal. Khusunya untuk remaja stunted dan obesitas disarankan untuk mengatur pola makan dan aktifitas fisik sehingga dapat mengurangi risiko resistensi insulin dan sindrom metabolik.

\section{UCAPAN TERIMAKASIH}

Peneliti mengucapkan terimakasih kepada subjek penelitian dan semua pihak yang telah membantu penelitian ini.

\section{DAFTAR PUSTAKA}

1. Badan Penelitian dan Pengembangan Kesehatan. Riset Kesehatan Dasar. 306, (2013).

2. Santoso, B., Sulistiowati, E., Sekartuti \& Lamid, A. Kementerian Kesehatan RI, Pokok Pokok Hasil Riskesdas Provinsi Jawa Tengah 2013. (Lembaga Penerbitan Badan Penelitian dan Pengembangan Kesehatan Kementerian Kesehatan RI, 2013).

3. Fernald, L. C. \& Neufeld, L. M. Overweight with concurrent stunting in very young children from rural Mexico: prevalence and associated factors. Eur. J. Clin. Nutr. 61, 623-32 (2006).

4. Florêncio, T. T., Ferreira, H. S., Cavalcante, J. C., Luciano, S. M. \& Sawaya, a L. Food consumed does not account for the higher prevalence of obesity among stunted adults in a very-low-income population in the Northeast of Brazil (Maceió, Alagoas). Eur. J. Clin. Nutr. 57, 1437-1446 (2003).

5. D.J.P. Barker, C. O. INFANT MORTALITY, CHILDHOOD NUTRITION, AND ISCHAEMIC HEART DISEASE IN ENGLAND AND WALES. Lancet 327, No. 8, 1077-1081 (1986).

6. Hoffman, D. J., Sawaya, A. L., Verreschi, I., Tucker, K. L. \& Roberts, S. B. Why are nutritionally stunted children at increased risk of obesity? Studies of metabolic rate and fat oxidation in shantytown children from Sao Paulo, Brazil. Am. J. Clin. Nutr. 72, 702-707
(2000).

7. Kruger, H. S. PEDIATRIC HIGHLIGHT Association between stunting and overweight among $10-15$-y-old children in the North West Province of South Africa : the THUSA BANA Study. 842-851 (2004). doi:10.1038/sj.ijo.0802586

8. Sawaya, A. L. Stunting and future risk of obesity: principal physiological mechanisms Baixa estatura nutricional e risco de obesidade futura: principais mecanismos fisiológicos. 19, 21-28

9. Santos, C. D. D. L., Clemente, A. P. G., Martins, V. J. B., Albuquerque, M. P. \& Sawaya, A. L. Adolescents with mild stunting show alterations in glucose and insulin metabolism. J. Nutr. Metab. 2010, (2010).

10. Barnard, R. J. et al. Diet-induced insulin resistance precedes other aspects of the metabolic syndrome. 2, 1311-1315 (1998).

11. Christian K.Roberts, Andrea L.Hevener, and R. J. B. Metabolic Syndrome and Insulin Resistance: Underlying Causes and Modification by Exercise Training. Compr Physiol 3, 1-58 (2014).

12. Reaven, G. M. Banting Lecture 1988 Role of Insulin Resistance in Human. 37, 1595-1607 (1988).

13. Grundy, S. M., Brewer, H. B., Cleeman, J. I., Smith, S. C. \& Lenfant, C. Definition of Metabolic Syndrome: Report of the National Heart, Lung, and Blood Institute/American Heart Association Conference on Scientific Issues Related to Definition. Circulation 109, 433-438 (2004).

14. Baranova, A., Tran, T. P., Birerdinc, A. \& Younossi, Z. M. Alimentary Pharmacology and Therapeutics Systematic review: association of polycystic ovary syndrome with metabolic syndrome and non-alcoholic fatty liver disease. 801-814 (2011). doi:10.1111/j.1365-2036.2011.04579.x

15. Abbasi, F., Brown, B. W., Lamendola, C., McLaughlin, T. \& Reaven, G. M. Relationship between obesity, insulin resistance, and coronary heart disease risk. $J$. Am. Coll. Cardiol. 40, 937-943 (2002).

16. Haffner, S. M. et al. Prospective Analysis of the Insulin-Resistance Syndrome (Syndrome X). 41, 715722 (1992).

17. Baron, D., Roudebush, R. L. \& Hemodynamic, A. D. actions of insulin. (1994).

18. Danusa, C. et al. Adolescents with Mild Stunting Show Alterations in Glucose and Insulin Metabolism. 2010, (2010).

19. Rocco, E. R. et al. Optimal cutoff points for body mass index, waist circumference and HOMA-IR to identify a cluster of cardiometabolic abnormalities in normal glucose-tolerant Brazilian children and adolescents. 55, (2011).

20. Csont, T. Determination of serum insulin level by ELISA. 1-13

21. Velasco, M. Biologic Behavior and optimal cut-off point estimation for Serum Fasting Insulin: A report from the Maracibo City... (2012).

22. Pencegahan, P. D. A. N. \& Indonesia, D. I. Pengelolaan dan pencegahan diabetes melitus tipe 2 di indonesia 2015. (2015).

23.Ziraba, A. K., Fotso, J. C. \& Ochako, R. Overweight and obesity in urban Africa: A problem of the rich or 
the poor? 9, 1-9 (2009).

24. Cuong, T. Q., Dibley, M. J., Bowe, S., Hanh, T. T. M. \& Loan, T. T. H. Obesity in adults: an emerging problem in urban areas of Ho Chi Minh City , Vietnam. 673-681 (2007). doi:10.1038/sj.ejcn.1602563

25. Do, L. M. et al. Preschool overweight and obesity in urban and rural Vietnam: differences in prevalence and associated factors. 1, 1-10 (2015).

26. Ong, K., Dunger, D. B. \& Zegher, F. De. Early Development of Adiposity and Insulin Resistance after Catch-Up Weight Gain in Small-for-Gestational-Age. 91, 2153-2158 (2016).

27. Hoffman, D. J. et al. Energy expenditure of stunted and nonstunted boys and girls living in the shantytowns of São Paulo, Brazil 1 - 3. 1025-1031 (2000).

28. Kirchengast, S. Gender Differences in Body Composition from Childhood to Old Age: An Evolutionary Point of View. 2, 1-10 (2010).

29. Blaak, E. Gender differences in fat metabolism. (2001).

30. Ramos, C. V, Dumith, S. C. \& César, J. A. Prevalence and factors associated with stunting and excess weight in children aged 0-5 years from the Brazilian semi-arid region \&. 91, 175-177 (2015).

31. F.r. Alves, J., P.a. Britto, R., S. Ferreira, H., L. Sawaya, A. \& M.m.t. Florêncio, T. Evolution of the biochemical profile of children treated or undergoing treatment for moderate or severe stunting: Consequences of metabolic programming? J. Pediatr. (Rio. J). 90, 356362 (2014).

32. Jana Parizkova, A. H. Childhood Obesity Prevention and Treatment. (crc press, 2004).

33. Hoffman, D. J. et al. Community and International Nutrition Regulation of Energy Intake May Be Impaired in Nutritionally Stunted Children from the Shantytowns of Sa. 2265-2270 (2000).

34. A transgenic model of visceral obesity and the metabolic syndrome Importance of a single subunit for G-protein activation within a heterodimeric receptor. 13, 2760 (2002).

35. Rizzo, A. C. B., Goldberg, T. B. L., Silva, C. C., Kurokawa, C. S. \& Nunes, H. R. C. Metabolic syndrome risk factors in overweight, obese, and extremely obese brazilian adolescents. 1-7 (2013).

36. Khiqmah, A. N. ASUPAN GULA SEDERHANA DAN SERAT SERTA KADAR GLUKOSA DARAH PUASA ( GDP ) SEBAGAI FAKTOR RISIKO PENINGKATAN KADAR C-REACTIVE PROTEIN ( CRP ) PADA REMAJA OBESITAS DENGAN. (2014).

37. Bergman, R. N. et al. Why Visceral Fat is Bad: Mechanisms of the Metabolic Syndrome. 14, 3-6 (2006).

38. Miranda, P. J., Defronzo, R. A. \& Califf, R. M. Metabolic syndrome: Definition, pathophysiology, and mechanisms. 33-45 (2005). doi:10.1016/j.ahj.2004.07.013

39. Tripathy, D. et al. Elevation of Free Fatty Acids Induces Inflammation and Impairs Vascular Reactivity in Healthy Subjects. 52, 2-7 (2003).

40. Cianfarani, S., Germani, D. \& Branca, F. Low birthweight and adult insulin resistance : the ' catch-up growth ' hypothesis. 71-73 (1999).

41. Godfrey, K. M. \& Barker, D. J. P. Fetal nutrition and adult disease $1-3.71,1344-1352$ (2000).

42. Cianfarani, S. Foetal origins of adult diseases : just a matter of stem cell number? 61, 401-404 (2003).

43. Deng, H., Li, Y. \& Su, Z. Association between height and weight catch-up growth with insulin resistance in pre-pubertal Chinese children born small for gestational age at two different ages. 75-80 (2011). doi:10.1007/s00431-010-1274-8

44. Woods, K. A. et al. The Somatotropic Axis in Short Children Born Small for Gestational Age : Relation to Insulin Resistance. 51, 76-80 (2002).

45. Kruger, H. S., Pretorius, R. \& Schutte, A. E. Stunting, adiposity, and low-grade inflammation in African adolescents from a township high school. Nutrition 26, 90-99 (2010).

46. Prendergast, A. J. et al. Stunting is characterized by chronic inflammation in zimbabwean infants. PLoS One 9, (2014).

47. Tewari, N., Awad, S., Macdonald, I. a \& Lobo, D. N. Obesity-related insulin resistance: implications for the surgical patient. Int. J. Obes. 39, 1575-1588 (2015).

48. Chang, J., Chen, H., Su, H. \& Lee, C. Abdominal Obesity and Insulin Resistance in People Exposed to Moderate-to-High Levels of Dioxin. 1-14 (2016). doi:10.1371/journal.pone.0145818

49. Virtanen, K. A. et al. Increased Fat Mass Compensates for Insulin Resistance in Abdominal Obesity and Type 2 Diabetes. 54, (2005).

50. SYDNEY A. WESTPHAL, M. Obesity , Abdominal Obesity, and. 9, 23-31 (2008).

51. Balkau, B., Mhamdi, L., Oppert, J. \& Nolan, J. Physical activity and insulin sensitivity the RISC study. Diabetes 57, 2613-2618 (2008).

52. Kwak, H.-B. Exercise and obesity-induced insulin resistance in skeletal muscle. Integr. Med. Res. 2, 131138 (2013).

53. Dipietro, L. et al. Exercise and improved insulin sensitivity in older women : evidence of the enduring benefits of higher intensity training. 6519, 142-149 (2006)

54. Vrbíková, J. et al. Family History of Diabetes Mellitus Determines Insulin Sensitivity and B Cell Function in Polycystic Ovary Syndrome. 8408, 547-553 (2008).

55. Family History of Type 2 Diabetes Is Sensitivity and an Impaired Balance Between Insulin Sensitivity and Insulin Secretion in White Youth. 28, (2005). 